\title{
Lower level of IL-35 and its reduced inhibition in Th17 cells in patients with bone marrow mononuclear cells Coombs test-positive hemocytopenia
}

\author{
YI LI* , YIHAO WANG* ${ }^{*}$, HUI LIU, KAI DING, SHANFENG HAO, YUANYUAN SHAO, \\ HONGLEI WANG, JIN CHEN, LEI HUANG, ZONGHONG SHAO and RONG FU \\ Department of Hematology, Tianjin Medical University General Hospital, Tianjin 300052, P.R. China
}

Received January 4, 2017; Accepted August 10, 2017

DOI: $10.3892 / \mathrm{mmr} .2017 .8252$

\begin{abstract}
Interleukin (IL)-35 is the latest member of IL-12 family, which plays an important role in other autoimmune diseases. Bone marrow mononuclear cells Coombs test-positive hemocytopenia, also termed immunorelated hemocytopenia (IRH) is a type of autoimmune-associated diseases. The present study investigated the relationship of IL-35 in patients with IRH. A total of 43 patients with IRH and 19 normal controls were enrolled in the current study. Serum levels of IL-35 and IL-17 in peripheral blood were evaluated by ELISA. Regulatory T cells (Tregs) level was detected by flow cytometry and IL-35 subunits mRNA in Treg was determined using reverse transcription-quantitative polymerase chain reaction: Epstein-Barr virus induced 3 (EBI3) and IL-12 $\alpha$ chain p35. Effect of IL-35 on Thelper 17 cells (Th17) cells was determined by mix-culture of IL-35 with CD4 ${ }^{+}$T lymphocytes. Serum level of IL-35 was decreased in untreated patients with IRH compared with remission patients $(\mathrm{P}<0.01)$ and was significantly associated with clinical indexes. Frequency of IL-35 produced Tregs was lower and IL-35 subunits mRNA in $\mathrm{CD} 4{ }^{+} \mathrm{CD} 25^{+}$Tregs were decreased in patients with IRH compared with health controls $(\mathrm{P}<0.01)$. Serum level of IL-17 was increased in patients with IRH $(\mathrm{P}<0.01)$ and there was a negative correlation between IL-35 and IL-17 ( $r=-0.553 ; \mathrm{P}<0.01)$. The production of Th17 cells and IL-17A mRNA expression were reduced $(\mathrm{P}<0.05)$ after mix-culture of CD4 $4^{+} \mathrm{T}$ lymphocytes with IL-35 compared with mix-culture of $\mathrm{CD} 4^{+} \mathrm{T}$ lymphocytes without IL-35. In conclusion, the present study revealed that IL-35 may be a
\end{abstract}

Correspondence to: Dr Zonghong Shao or Dr Rong Fu, Department of Hematology, Tianjin Medical University General Hospital, 154 Anshan Street, Heping, Tianjin 300052, P.R. China

E-mail: shaozonghong@sina.com

E-mail: florai@sina.com

${ }^{*}$ Contributed equally

Key words: immunorelated hemocytopenia, autoimmune disease, decrease, interleukin 35, Treg, T helper 17 cell monitoring indicator of IRH occurrence and progression. IL-35 level was lower and the inhibition on Th17 cells was reduced in the patients with IRH.

\section{Introduction}

The heterodimeric cytokine of interleukin (IL)-35, as a newly identified member of the IL-12 family, is likely to contribute to the development of autoimmune diseases. It is formed by Epstein-Barr virus induced 3 (EBI3) associated with IL-12p35. IL-35 was demonstrated to be expressed in mouse $\mathrm{CD}^{+} \mathrm{CD} 25^{+} \mathrm{Foxp}^{+}$regulatory $\mathrm{T}$ cells (Tregs) (1) and was then demonstrated to be expressed by naturally occurring $\mathrm{CD}^{+}{ }^{+} \mathrm{CD} 25^{+}$Tregs isolated from human peripheral blood mononuclear cells instead of $\mathrm{CD} 4^{+} \mathrm{CD} 25^{-}$conventional responder T cells (Tres) (2). It can downregulate the development of $\mathrm{T}$ helper type 17 (Th17) cells and then inhibit autoimmune inflammation in other autoimmune diseases $(2,3)$ and may occur in type 1 cytokine [interferon- $\gamma($ IFN- $\gamma)$, tumor necrosis factor-a (TNF- $\alpha$ ) and IL-2 mediated]/type 17 (IL-17A and IL-17F mediated) and type 2 [IL-4, transforming growth factor (TGF)- $\beta$ mediated] immune-inflammatory diseases.

Bone marrow mononuclear cells (BMMNC)-Coombs test-positive hemocytopenia, also termed immunorelated hemocytopenia (IRH) is a type of hemocytopenia exhibiting these following features: i) Hemocytopenia or pancytopenia with a normal or higher percentage of reticulocytes and/or neutrophils; ii) hyperplasia-bone marrow (BM) with a higher percentage of nucleated erythroid cells in sternum, with erythroblastic islands (EIs) that were easily observed; iii) good responses to corticosteroids or high-dose intravenous immunoglobulin (IVIg); iv) exclusion of other primary and secondary hemocytopenia disorders; and v) positive result by BMMNC-Coombs test $(4,5)$. This disease is an immuno-associated hemocytopenia and the production of the autoantibodies may be due to the abnormal number and function of B lymphocytes (6), regulatory T cells (7) and Th17 (8).

To investigate its interrelationship and immunopathological role in IRH, the present study determined the level of IL-35 and its Treg cells in relation to the progression of this disease. The present study detected the serum IL-17 concentration on this autoimmune disease to test the connection between IL-35 
and Th17 cells. Additionally, CD4 ${ }^{+} \mathrm{T}$ lymphocytes were sorted to culture with IL-35 and determine its effect on Th17 cell differentiation.

\section{Patients and methods}

Patients. A total of 43 (25 females and 18 males; median age, 36 years; range, 11-69 years) patients with IRH were enrolled in the current study, including 18 untreated patients (11 females and 7 males; median age, 44.5 years; range, $16-68$ years) and 25 in remission (14 females and 11 males; median age, 31 years; range, 11-69 years). All were inpatients in the Department of Hematology, Tianjin Medical University General Hospital (Tianjin, China) between August 2015 and September 2016 and diagnosed according to $\mathrm{Fu}$ (5). Patients were given corticosteroids (prednisone, $0.5 \mathrm{mg} / \mathrm{kg} /$ day) and cyclosporine (CsA) (3 mg/kg/day) as immunosuppressive therapy and some received high-dose IVIg $(0.4 \mathrm{~g} / \mathrm{kg} /$ day for 5 days; Chengdu Institute of Biological Products, Sichuan, China) if they depend on blood transfusion. Complete blood count (CBC) and bone marrow $(\mathrm{BM})$ examination were performed regularly. The response criteria were measured according to those of aplastic anemia (AA) (9) and the median follow-up time was 12 months (range, 3-21 months). A total of 19 healthy volunteers with normal blood picture and immune parameters ( 9 females and 10 males; median age, 32 years; range, 22-48 years) were selected as normal controls. The current study was approved by the Ethical Committee of the Tianjin Medical University and written informed consent was obtained from the patients for the publication of the current study.

Enzyme-linked immunosorbent assay (ELISA). Serum levels of IL-35 and IL-17 in patients with IRH and normal control individuals were measured using ELISA reagent kits (cat. nos. SEC008Hu and SEA063Hu; USCN LIFE, Wuhan, China) according to the manufacturer's protocol. Diluted standards and patient serum $(100 \mu \mathrm{l})$ were added in duplicate and incubated at $37^{\circ} \mathrm{C}$ for $2 \mathrm{~h}$. After washing the plate 5 times, $100 \mu \mathrm{l}$ of antibody was added to each well and incubated at room temperature for $90 \mathrm{~min}$ and horseradish peroxidase was added to each well. Following incubation at $37^{\circ} \mathrm{C}$ for $30 \mathrm{~min}$, the wells were washed 5 times. Subsequently, tetramethylbenzidine solution was added to each well and the samples were incubated in the dark at room temperature for $20 \mathrm{~min}$. Finally, a stop solution was added, and the optical density was read at $450 \mathrm{~nm}$ within $15 \mathrm{~min}$.

Purification of T lymphocyte subsets using MACS micro bead technology. Using Ficoll-Hypaque density gradient centrifugation to isolate peripheral blood mononuclear cells (PBMCs) from heparin anticoagulant venous blood of IRH and normal controls, diluted blood was diluted 1:1 in Ficoll-Hypaque fluid and then centrifuged at $400 \mathrm{xg}$ for $20 \mathrm{~min}$ at $4^{\circ} \mathrm{C}$. The interface was collected and washed with PBS at $300 \mathrm{x} g$ for $10 \mathrm{~min}$. $\mathrm{CD} 4^{+} \mathrm{T}$ lymphocytes were purified using $\mathrm{CD} 4^{+} \mathrm{T}$ cell isolation kit (130096533; Miltenyi Biotec GmbH, Bergisch Gladbach, Germany) according to the manufacturer's protocol. Every $10^{7}$ PBMCs were resuspended in $40 \mu \mathrm{l}$ of buffer. Then $10 \mu \mathrm{l}$ CD4 Biotin-Antibody cocktail (Miltenyi Biotec $\mathrm{GmbH}$ ) was added and incubated at $4^{\circ} \mathrm{C}$ in the dark for $5 \mathrm{~min}$. After that, $30 \mu \mathrm{l}$ buffer was added and $20 \mu \mathrm{l}$ of Anti-Biotin micro beads. Finally, cells were resuspended up in $500 \mu \mathrm{l}$ of buffer. The LS column was placed in the magnetic field of a suitable MACS separator (Miltenyi Biotec $\mathrm{GmbH}$ ). After preparing the column by rinsing with $3 \mathrm{ml}$ buffer, the cells were added into the column. The column was washed with $3 \mathrm{ml}$ buffer and all unlabeled CD4 ${ }^{+}$ $\mathrm{T}$ cells that passed through were collected. Some of the isolated $\mathrm{CD}^{+} \mathrm{T}$ cells were resuspended in $90 \mu \mathrm{l}$ per $10^{7}$ cells and using anti-CD25 mAb-conjugated microbeads (130092983; Miltenyi Biotec $\mathrm{GmbH}$ ) to isolate the $\mathrm{CD} 4{ }^{+} \mathrm{CD} 25^{+}$Tregs and $10 \mu \mathrm{l} \mathrm{CD} 25$ MicroBeads were added in the sorting system. Following incubation for an additional $15 \mathrm{~min}$ at $4^{\circ} \mathrm{C}$ in the dark, cells were washed by adding $2 \mathrm{ml}$ buffer and resuspended up to $500 \mu \mathrm{l}$ every $10^{8}$. The MS column was placed in the magnetic field of a suitable MACS separator. After preparing the column by rinsing with $1.5 \mathrm{ml}$ buffer, the cells were applied into the column. The column was washed with $1.5 \mathrm{ml}$ buffer and all flow-through containing unlabeled cells was collected. Magnetically labeled cells were immediately flushed out by firmly pushing the plunger into the column and finally the $\mathrm{CD} 4{ }^{+} \mathrm{CD} 25^{+}$Tregs were collected. Sorted collection was incubated with CD4-FITC (130092358; 1:10) and CD25-APC (130092858; 1:10; Miltenyi Biotec $\mathrm{GmbH}$ ) in the dark for 5 min and mouse IgG1-FITC, IgG2b-APC (130098847 and 130098890; 1:10; Miltenyi Biotec $\mathrm{GmbH}$ ) were used to stain the negative controls. Then the purity was tested by flow cytometry (FCM).

Mixed-culture of $I L-35$ and $\mathrm{CD}^{+} T$ lymphocytes. $\mathrm{CD} 4^{+}$ $\mathrm{T}$ lymphocytes from 5 untreated IRH patients were seeded at $2 \times 10^{6}$ cell $/ \mathrm{ml}$ in the 24 well plates in cell medium RPMI 1640 supplemented (Beijing Solarbio Science and Technology Co., Ltd., Beijing, China) with $15 \%$ fetal bovine serum (FBS). Each patient's $\mathrm{CD} 4^{+} \mathrm{T}$ lymphocytes were divided into 3 groups and cultured with: i) Blank control, group (a); ii) $1 \mu \mathrm{g} / \mathrm{ml}$ anti-CD3 MAbs (BioLegend, Inc., San Diego, CA, USA), $10 \mu \mathrm{g} / \mathrm{ml}$ anti-CD28 MAbs (BioLegend, Inc.), $20 \mathrm{ng} / \mathrm{ml}$ TGF- $\beta$ (Peprotech, Rocky Hill, CT, USA), 50 ng/ml IL-6 (Peprotech) to promote differentiation to Th17 cells, group (b); and iii) $1 \mu \mathrm{g} / \mathrm{ml}$ anti-CD3 MAbs (BioLegend, Inc.), $10 \mu \mathrm{g} / \mathrm{ml}$ anti-CD28 MAbs (Biolegeng), $20 \mathrm{ng} / \mathrm{ml}$ TGF- $\beta$ (Peprotech), $50 \mathrm{ng} / \mathrm{ml}$ IL-6 (Peprotech), $50 \mathrm{ng} / \mathrm{ml} \mathrm{IL-35} \mathrm{(Peprotech)} \mathrm{to} \mathrm{find}$ out whether IL-35 may inhibit the differentiation of CD4 ${ }^{+}$ T lymphocytes to Th17 cells, group (c), then incubated at $37^{\circ} \mathrm{C}$, $5 \% \mathrm{CO}_{2}$ for 3 days.

Reverse transcription-quantitative polymerase chain reaction $(R T-q P C R)$. RT-qPCR was used to investigate IL-35 mRNA in Tregs and gp130, IL-12R-32, RAR-related orphan receptor (ROR) $\gamma \mathrm{t}$ and IL-17a mRNA in mix-cultured $\mathrm{CD} 4^{+} \mathrm{T}$ lymphocytes. Total RNA was isolated from Tregs/cultured $\mathrm{CD}^{+} \mathrm{T}$ lymphocytes using TRIzol reagent (Takara Biotechnology Co., Ltd., Dalian, China) from $1 \times 10^{5}$ isolated cells. A total $1 \mu \mathrm{g}$ RNA was converted to cDNA using reverse transcription with PrimeScript RT reagent kit at $37^{\circ} \mathrm{C}$ for 15 min then $5 \mathrm{sec}$ at $85^{\circ} \mathrm{C}$ for 1 cycle (Takara Biotechnology Co., Ltd.). qPCR was performed in a $25 \mu \mathrm{l}$ reaction volume containing $12.5 \mu \mathrm{l}$ of SYBR-Green (Takara Biotechnology Co., Ltd.). All primer sequences were presented in Table I. The thermocycling profile was as follows: $95^{\circ} \mathrm{C} 5 \mathrm{sec}$ and $60^{\circ} \mathrm{C} 45 \mathrm{sec}$ for 45 cycles. The relative quantity of target mRNA expression was calculates 
Table I. All primer sequences used in this research.

\begin{tabular}{lll}
\hline Gene & \multicolumn{1}{c}{ Sense $\left(5^{\prime}-3^{\prime}\right)$} & \multicolumn{1}{c}{ Anti-sense $\left(5^{\prime}-3^{\prime}\right)$} \\
\hline Ebi3 & TCCTTCATTGCCACGTACAG & GCTCTGTTATGAAAGGCACG \\
IL-12p35 & AAACCTCCCCGTGGCCACTCC & GAAGCATTCAGATAGCTCATCACT \\
gp130 & GCTGCGAGTTATTACTGGAG & TTATCATGGCACTCTGTTGAG \\
IL-12R- $\beta 2$ & AAAGAGGACGAGACACCCAC & GAAGAGGAGCTTCCAAGACT \\
ROR $\gamma \mathrm{t}$ & CTCCATCTTTGACTTCTCCCACTCCCTA & CACATGCTGGCTACACAGGCTC \\
IL-17a & CAGATTACTACAACCGAT & CATGTGGTAGTCCACGTTCC \\
$\beta$-actin & TGGACATCCGCAAAGACCTGT & CACACGGAGTACTTGCGCTCA
\end{tabular}

EBI3, Epstein-Barr virus induced 3; IL, interleukin; ROR, RAR-related orphan receptor.

using the quantification cycle $(\mathrm{Cq})$ method using the equation: Relative quantity $=2^{-\Delta \Delta \mathrm{Cq}}(10)$.

$F C M$. In order to determine the $\mathrm{CD}^{+} \mathrm{CD} 25^{+} \mathrm{Foxp} 3^{+}$cell level, fresh $200 \mu 1 \mathrm{~PB}$ samples were lysed with hemolysin (BD Pharmingen, Franklin Lakes, NJ, USA) and erythrocytes washed with PBS. CD4-fluorescein isothiocyanate (FITC) and CD25-APC (1:20; cat.nos. 130092358 and 130092858; Miltenyi Biotec $\mathrm{GmbH}$ ) were used as the fluorophore-conjugated monoclonal antibodies and IgG1-FITC, IgG2b-APC (1:20; cat nos. 130098847 and 130098890; Miltenyi Biotec GmbH) were used to stain the negative controls. The forkhead box P3 (FoxP3) Staining Buffer set (Miltenyi Biotec GmbH) was used for cell fixation and permeabilization. After that, cells were stained with FoxP3-phycoerythrin (PE; 1:2; cat. no. 130093014; Miltenyi Biotec $\mathrm{GmbH}$ ) or IgG1-PE (1:2; cat. no. 130098845; Miltenyi Biotec $\mathrm{GmbH}$ ) as negative control. Regulatory $\mathrm{T}$ cells were identified as $\mathrm{CD} 4^{+} \mathrm{CD} 25^{+} \mathrm{Foxp} 3^{+}$and the frequencies were determined.

To determine the Th17 cell level, PBMCs/mixed-culture $\mathrm{CD}^{+}{ }^{+} \mathrm{T}$ lymphocytes were incubated with $25 \mathrm{ng} / \mathrm{ml}$ phorbol ester (Beyotime Institute of Biotechnology, Shanghai, China), $1 \mu \mathrm{g} / \mathrm{ml}$ Brefeldin A (Beyotime Institute of Biotechnology) and $1 \mu \mathrm{g} / \mathrm{ml}$ Ionomycin (Beyotime Institute of Biotechnology) at $37^{\circ} \mathrm{C}$ for 5 h. Next, CD4-FITC (2:5; cat. no. 130092358; Miltenyi Biotec $\mathrm{GmbH}$ ) was used as the fluorophore conjugated monoclonal antibodies and mouse IgG1-FITC (1:5; cat. no. 130098847; Miltenyi Biotec $\mathrm{GmbH}$ ) were used to stain the negative controls. Following fixation and permeabilization with Cytofix/Cytoperm Buffer kit (BD Pharmingen, San Diego, CA, USA), cells were stained with IL-17A-PE (1:10; cat. no. 130094521) or IgG1-PE (1:10; cat. no. 130098845; both from Miltenyi Biotec $\mathrm{GmbH}$ ) as negative control. Th17 cells were identified as CD4 ${ }^{+} \mathrm{IL}-17^{+}$ and the frequencies were determined. At least $10^{4}-10^{5}$ cells were acquired and analyzed by FACS Calibur flow cytometer (BD Biosciences) and CellQuest software version 6.0.

Autoantibodies on the membrane of BM hematopoietic cells by FCM analysis. The positive rates of autoantibodies were tested by FCM on granulocytes $\left(\mathrm{CD} 15^{+}\right)$, stem cells $\left(\mathrm{CD} 34^{+}\right)$, nucleated erythrocytes $\left(\mathrm{GlyCoA}^{+}\right)$using antibodies against CD15-FITC, CD34-FITC, GlycoA-FITC (5233893, 6082713 and 5288793; 1:10; BD Biosciences) and anti-human IgG-PE, IgM-APC antibodies (6144699 and 6042621; 1:10; BD Biosciences).
As described in our previous study (5) a value of $>4.0 \%$ was defined as positive. From these findings, all the enrolled patients with IRH were divided into three groups: i) Untreated patients; ii) remission patients with positive FCM results (remission ${ }^{+}$); and iii) remission patients with negative FCM result (remission-).

Statistical analysis. The SPSS version 21.0 (IBM Co., Armonk, NY, USA) was used for statistical analysis. Data are presented as mean \pm standard deviation. The significance of the differences was assessed by one-way analysis of variance, followed by multiple post hoc comparisons using the least significant difference test for homogeneous variances or Tamhane test for non-homogeneous variances. Correlation between patient characteristics was tested using Spearman's rank correlation test. $\mathrm{P}<0.05$ was considered to indicate statistically significant difference.

\section{Results}

Decreased serum level of IL-35 in peripheral blood samples from patients with IRH. All enrolled patients with IRH and normal controls serum levels of IL-35 were detected using a standard ELISA. As presented in Fig. 1A, untreated patients had significantly lower serum level of IL-35 $(20.59 \pm 6.047 \mathrm{pg} / \mathrm{ml})$ than the remission patients $(30.737 \pm 10.6 \mathrm{pg} / \mathrm{ml} ; \mathrm{P}<0.01)$ and normal controls $(98.45 \pm 57.016 \mathrm{pg} / \mathrm{ml} ; \mathrm{P}<0.01)$. Furthermore, serum levels of IL-35 in remission patients were lower than normal controls $(\mathrm{P}<0.01)$.

Correlation between IL-35 and clinical data of patients with IRH. In order to assess the correlation between serum level of IL-35 and clinical data of the patients, the Spearman's correlation coefficient was performed (Table II). These correlations were made only among IRH patients' clinical data and serum levels of IL-35. It is evident that the IL-35 level was significantly positively correlated with hemoglobin concentration, white blood cell counts and platelet counts $(\mathrm{P}<0.01, \mathrm{r}=0.620$; $\mathrm{P}<0.01, \mathrm{r}=0.429)$. However, it seemed that the IL-35 concentration was not associated with neutrocyte count and reticulocyte proportion $(\mathrm{P}=0.92, \mathrm{r}=0.055 ; \mathrm{P}=0.632, \mathrm{r}=0.045)$. $\mathrm{FCM}$ analysis was used to identify the frequencies of $\mathrm{CD}^{+} \mathrm{CD} 19^{+} \mathrm{B}$ cell gating on $\mathrm{CD} 19^{+} \mathrm{B}$ cell population and lymphocyte population. Negative correlation was identified between the serum IL-35 concentration and the frequencies of $\mathrm{CD}^{+} \mathrm{CD} 19^{+} \mathrm{B}$ cell gating 
Table II. Serum level of IL-35 correlations with clinical blood picture.

\begin{tabular}{lcccccr}
\hline & $\mathrm{n}$ & Median & Range & + - & P-value & $\mathrm{r}$ \\
\hline $\mathrm{Hb}(\mathrm{g} / \mathrm{l})$ & 43 & 89 & $41-149$ & + & 0.01 & 0.620 \\
$\mathrm{WBC}\left(\mathrm{x} 10^{\%} / \mathrm{l}\right)$ & 43 & 4 & $1.12-14.96$ & + & 0.01 & 0.429 \\
$\mathrm{~N}(\%)$ & 43 & 51.2 & $12.3-89$ & $\mathrm{~N}$ & 0.92 & 0.055 \\
$\mathrm{Plt}\left(\mathrm{x} 10^{9} / \mathrm{l}\right)$ & 43 & 40 & $6-149$ & + & 0.01 & 0.558 \\
$\mathrm{Ret}(\%)$ & 43 & 1.91 & $0.4-3.76$ & $\mathrm{~N}$ & 0.632 & 0.045 \\
$\mathrm{CD}^{+} \mathrm{CD} 19^{+}(\%)$ & 37 & 0.77 & $0.11-5.53$ & - & 0.028 & -0.295 \\
$\mathrm{CD}^{+} \mathrm{CD} 19^{+} / \mathrm{CD} 19^{+}(\%)$ & 37 & 12.04 & $3.29-38.74$ & - & 0.005 & -0.308 \\
\hline
\end{tabular}

$\mathrm{Hb}$, hemoglobin concentration; WBC, white blood cell counts; N, neutrocyte proportion; Plt, platelet counts; Ret, reticulocyte proportion; n, number of people enrolled; +, positive correlation; -, negative correlation; $\mathrm{N}$, no correlation.

A

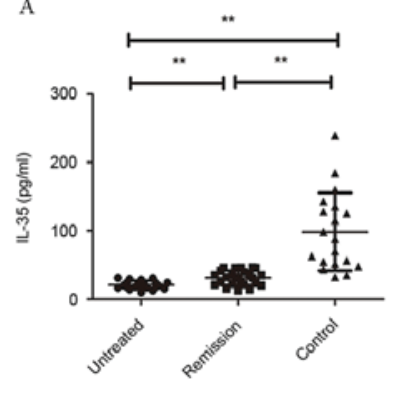

E
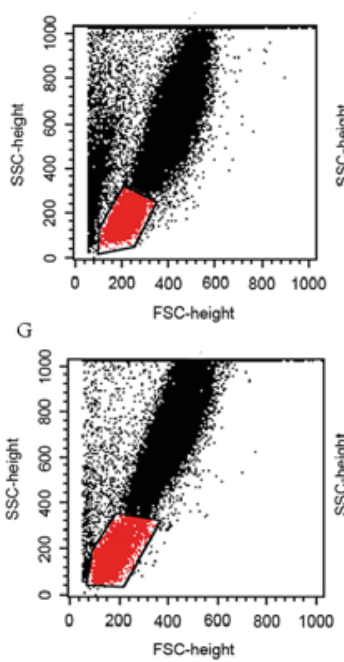

B
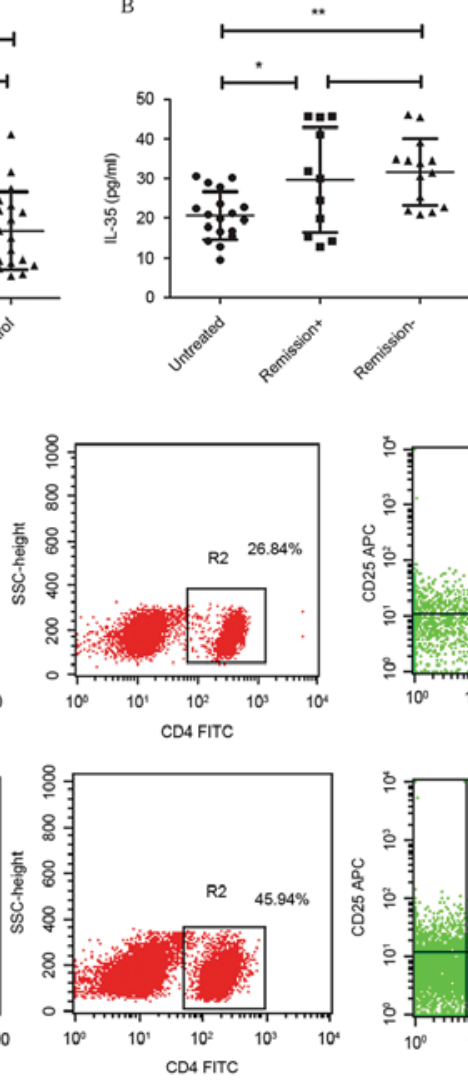

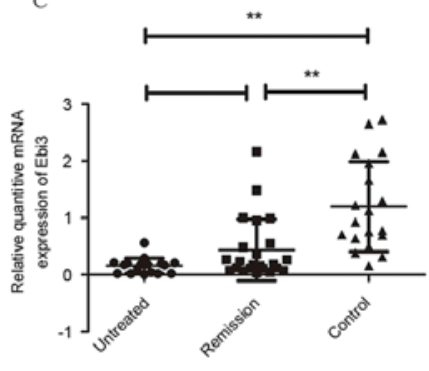

D

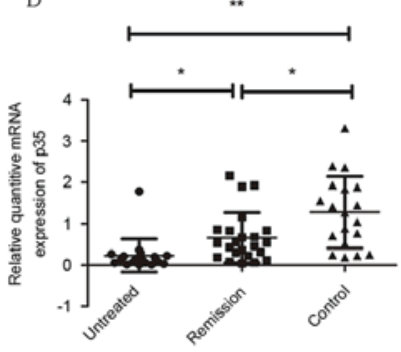

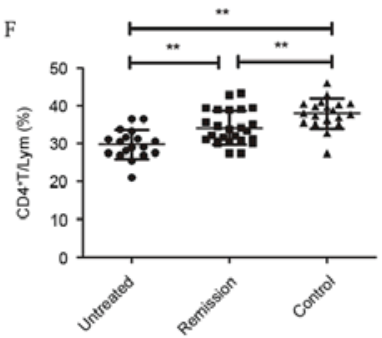

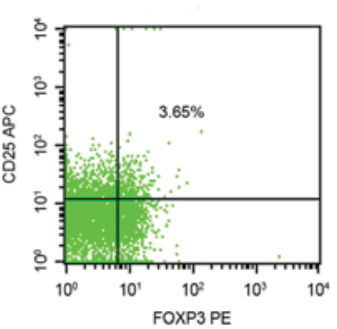

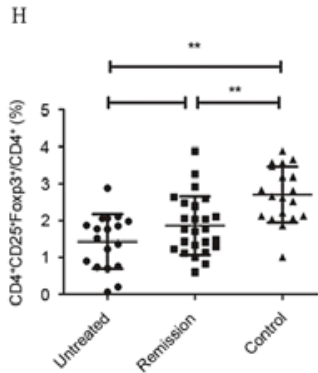

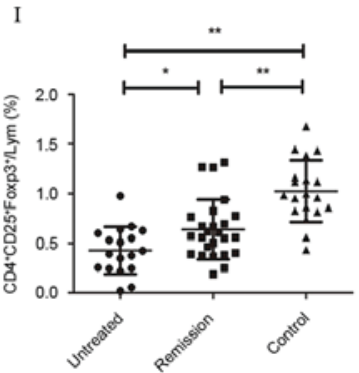

Figure 1. (A) Serum level of IL-35 was from untreated IRH patients ( $\mathrm{n}=18)$, remission patients ( $\mathrm{n}=25)$ and normal controls ( $\mathrm{n}=19)$. (B) Serum level IL-35 was from IRH patients $(\mathrm{n}=18)$, remission patients with positive cell membrane antibodies (remission ${ }^{+}$, $\mathrm{n}=11$ ) and negative cell membrane antibodies (remission ${ }^{-}$ $\mathrm{n}=14$ ) according to the cell membrane antibody results. Relative mRNA expression of (C) EBI3 and (D) p35 in isolated CD4 ${ }^{+} \mathrm{CD} 25^{+}$Tregs from untreated patients $(n=18)$, remission patients $(n=21)$ and normal controls $(n=19)$ detected by reverse transcription-quantitative polymerase chain reaction. Level of Tregs $\left(\mathrm{CD} 4^{+} \mathrm{CD} 25^{+} \mathrm{Foxp}^{+}\right)$in peripheral blood in untreated patients $(\mathrm{n}=18)$, remission patients $(\mathrm{n}=21)$ of IRH and normal controls $(\mathrm{n}=19)$. $(\mathrm{E}) \mathrm{Level}$ of Tregs in IRH patients detected by flow cytometry. (F) Levels of CD4 ${ }^{+} \mathrm{T}$ cells in lymphocyte population (G) Level of Tregs in normal control detected by flow cytometry. (H) Level of Tregs in CD4 ${ }^{+} \mathrm{T}$ lymphocytes. (I) Level of Tregs in lymphocytes. Data were expressed as median and range. ${ }^{*} \mathrm{P}<0.05$, ${ }^{* *} \mathrm{P}<0.01$. IL-35, interleukin-35; IRH, immune-related hemocytopenia; EBI3, Epstein-Barr virus induced 3; Tregs, regulatory T cells; FOXP3, forkhead box P3.

on $\mathrm{CD} 19^{+} \mathrm{B}$ lymphocyte population and gating on lymphocyte population and the trend had statistical significance $(\mathrm{P}<0.01$, $\mathrm{r}=-0.308 ; \mathrm{P}=0.028, \mathrm{r}=-0.295)$.

From the 43 IRH patients, it is evident in Fig. 1B that the untreated group had the lowest IL-35 concentration $(20.59 \pm 6.047 \mathrm{pg} / \mathrm{ml})$ and there was a significant difference when compared with the remission ${ }^{-}$group $(31.6352 \pm 8.4148 \mathrm{pg} / \mathrm{ml}$;
$\mathrm{P}<0.01)$ than with the remission ${ }^{+}$group $(29.6624 \pm 8.4148 \mathrm{pg} / \mathrm{ml}$; $\mathrm{P}=0.013$ ). Additionally, remission ${ }^{+}$group had a lower serum level of IL-35 compared with the remission ${ }^{-}$group but no significant difference was identified $(\mathrm{P}=0.592)$.

mRNA expression levels of EBI3 and $p 35 . \mathrm{CD} 4{ }^{+} \mathrm{CD} 25^{+}$Tregs were sorted from 41 IRH patients and 19 normal control 
A

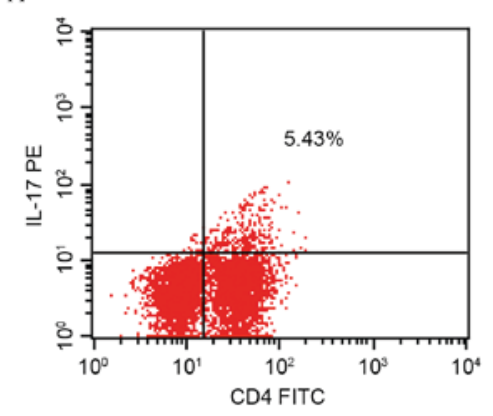

C
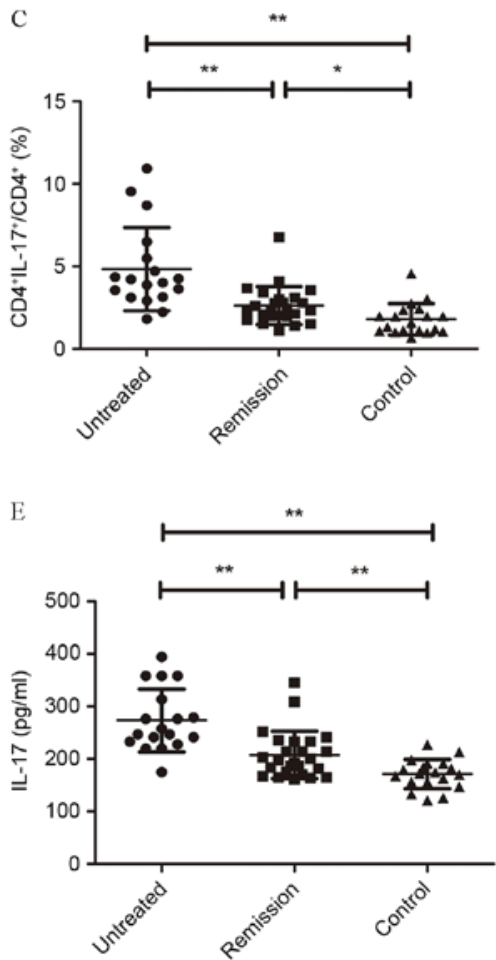

B

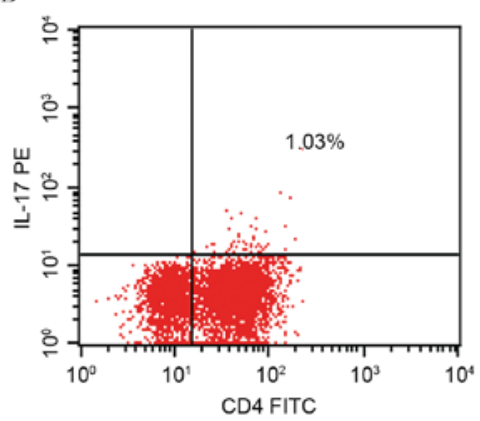

D

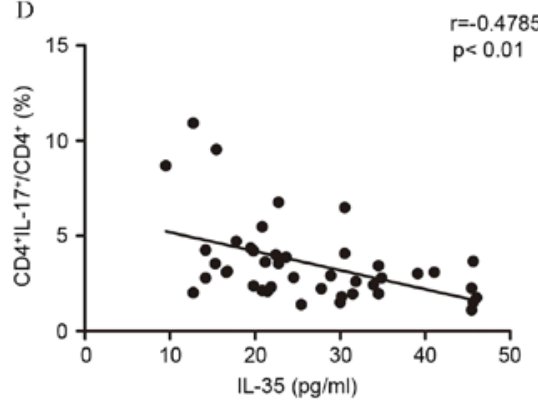

F

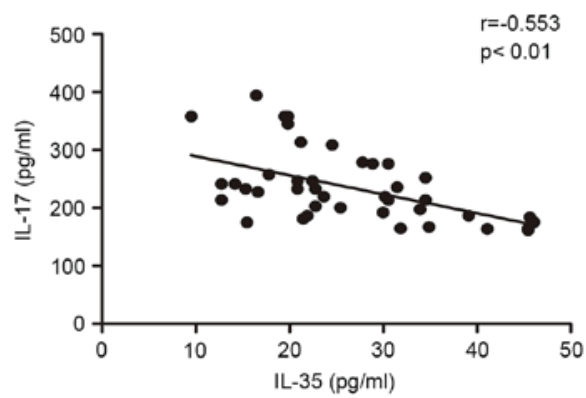

Figure 2. (A) Level of Th17 cells in patients with IRH detected by flow cytometry. Level of Tregs in (B) normal control and the percentage of (C) Th17 cells in $\mathrm{CD}^{+} \mathrm{T}$ lymphocytes. (D) Correlation between the level of Th17 cell and concentration of IL-35 in patients with IRH. Expression of PB serum level of IL-17 determined by ELISA. (E) Serum level of IL-17 of untreated IRH patients $(n=18)$, remission patients $(n=25)$ and normal controls $(n=19)$. Data were expressed as the median and range. (F) Correlation between IRH patient PB serum level of IL-17 and IL-35. ${ }^{*} \mathrm{P}<0.05,{ }^{* *} \mathrm{P}<0.01$. Th17, T helper 17 ; IRH, immune-related hemocytopenia; Tregs, regulatory T cells; IL, interleukin; PB, peripheral blood.

PBMC. The expression of IL-35 subsets in Tregs was assayed separately. Data are presented as the fold-change of gene expression normalized to the endogenous reference gene. As presented in Fig. 1C, the mRNA expression of EBI3 in patients with IRH, untreated $(n=18)$ and remission $(n=23)$, were lower compared with the normal control $(\mathrm{P}<0.01)$. The EBI3 mRNA expression in untreated patients was lower than the patients in remission; however, this was not statistically significant $(\mathrm{P}=0.124)$. The $\mathrm{p} 35 \mathrm{mRNA}$ expression in the untreated group was evidently the lowest of all the 3 groups ( $\mathrm{P}=0.027$ vs. remission patients; $\mathrm{P}<0.01$ vs. normal control; Fig. 1D). Additionally, expression level of p35 in the remission patients was also lower than the normal control $(\mathrm{P}=0.042)$.

Tregs by FCM analysis in PB. Circulating CD4+ ${ }^{+}$lymphocytes and regulatory $\mathrm{T}$ cells were identified by flow cytometric analysis of the IRH patients (Fig. 1E) and normal controls (Fig. 1G). The level of $\mathrm{CD}^{+}{ }^{+} \mathrm{T}$ cells in the lymphocyte population of the untreated IRH, remission IRH and normal control group was $29.8039 \pm 3.8688,34.1536 \pm 4.4754$, and $37.9705 \pm 6.047 \%$, respectively (Fig. 1F). All of the IRH patients had a significantly reduced level of $\mathrm{CD}^{+} \mathrm{T}$ cells compared with normal controls $(\mathrm{P}<0.01)$ and the untreated patients was even lower than that of the remission ones $(\mathrm{P}<0.01)$. Level of $\mathrm{CD}^{+}{ }^{+} \mathrm{CD} 25^{+}$Foexp3 ${ }^{+}$Tregs in $\mathrm{CD} 4^{+} \mathrm{T}$ lymphocytes of untreated and remission patients was $1.4333 \pm 0.7465$ and $1.8592 \pm 0.7935 \%$, were lower than that of the normal control group $(2.7032 \pm 0.7539 \%$; $\mathrm{P}<0.01$; Fig. $1 \mathrm{H})$. Additionally, level of Tregs in lymphocytes in untreated patients $(0.4269 \pm 0.2382 \%)$ and remission patents $(0.6389 \pm 0.3 \%)$ were lower than the of normal controls $(1.0245 \pm 0.3111 \%$; $\mathrm{P}<0.01$; Fig. 1I) and the untreated group was lower compared with the remission group $(\mathrm{P}=0.014)$.

Level of IL-35 and reduced inhibition on Th17 cells in patients with IRH. Th17 cells increased in untreated patients with IRH (Fig. 2A and B). The percentage of Th17 (CD4+IL-17 $\left.{ }^{+}\right)$ significantly increased in untreated patients $(4.83 \pm 2.53 \%)$ with 

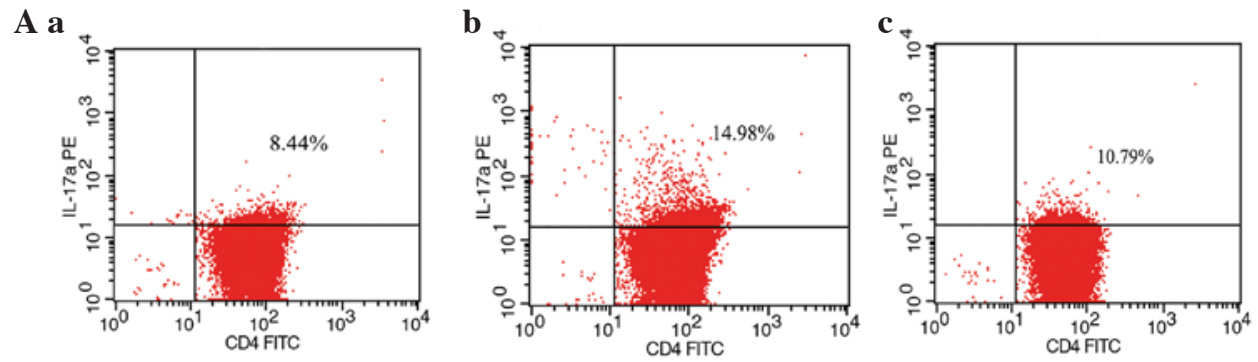

B

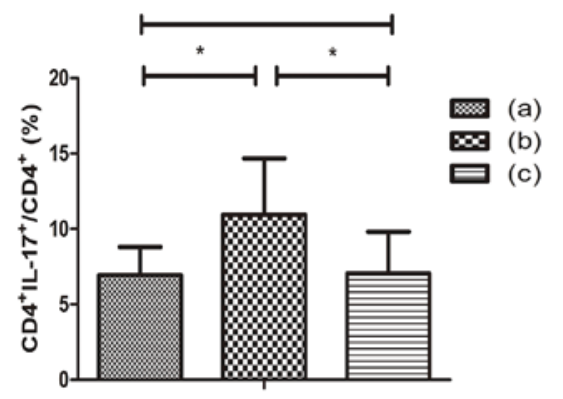

C

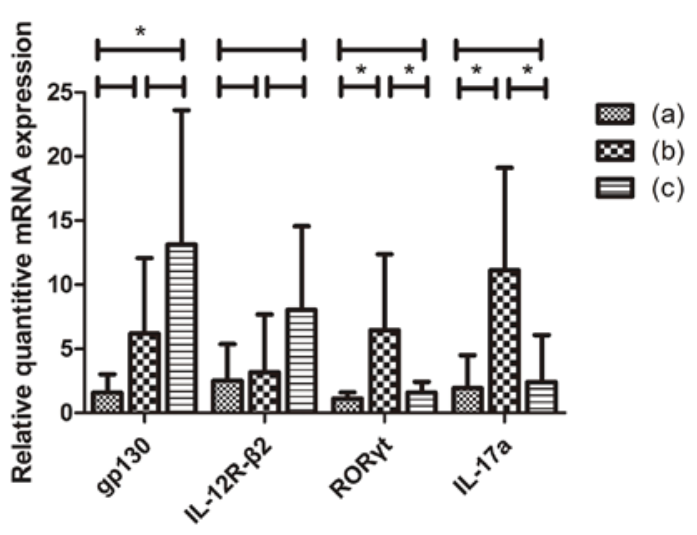

Figure 3. (A) Levels of Th17 cells in the 3 groups; (B) level of Th17 cells in CD4+ T cells population. (C) mRNA expression levels of gp130, IL-12R- $\beta 2$, $\mathrm{ROR} \gamma \mathrm{t}$, and IL-17a obtained using reverse transcription-quantitative polymerase chain reaction. " $\mathrm{P}<0.05$. group (a), blank control; group (b), anti-CD3 MAbs, anti-CD28 MAbs, TGF- $\beta$, IL-6; group (c), anti-CD3 MAbs, anti-CD28 MAbs, TGF- $\beta$, IL-6, IL-35. Th17, T helper 17; IL, interleukin; ROR, RAR-related orphan receptor; TGF, transforming growth factor.

IRH compared with normal controls $(1.8 \pm 0.92 \% ; \mathrm{P}<0.01)$ After the treatment, the percentage of Th17 significantly decreased $(\mathrm{P}<0.01)$, whereas it was still higher than normal controls ( $\mathrm{P}=0.036$; Fig. 2C). Correlation analysis between the percentage of Th17 cells in $\mathrm{CD} 4^{+} \mathrm{T}$ lymphocytes and serum level of IL-35 revealed a significant negative correlation $(r=-0.4785 ;$ P $<0.01 ;$ Fig. 2D).

Upregulated serum level of IL-17 in untreated patients with $I R H$. Serum level of IL-17 was determined in all enrolled patients. It was determined that untreated patients had significantly higher serum level of IL-17 $(273.479 \pm 59.7449 \mathrm{pg} / \mathrm{ml})$ than the remission patients $(206.5586 \pm 45.0886 \mathrm{pg} / \mathrm{ml} ; \mathrm{P}<0.01$; Fig. 2E) and normal controls (171.2928 $\pm 27.6907 \mathrm{pg} / \mathrm{ml} ; \mathrm{P}<0.01)$. Additionally, serum level of IL-17 in remission patients was higher than the normal controls $(\mathrm{P}<0.01)$. Significant negative correlation was identified between the serum level of IL-17 and IL-35 in patients with IRH ( $\mathrm{r}=-0.553 ; \mathrm{P}<0.01$; Fig. $2 \mathrm{~F})$.

Mixed-culture of IL-35 and $C D 4^{+} T$ lymphocytes. After a 3-day incubation in RPMI 1640 medium supplemented with $15 \%$ FBS with group: i) Blank control, group (a); ii) anti-CD3 MAbs, anti-CD28 MAbs, TGF- $\beta$, IL- 6 , group (b); and iii) anti-CD3 MAbs, anti-CD28 MAbs, TGF- $\beta$, IL-6, IL-35, group (c). The Th17 cells in the three groups were separately identified using FCM (Fig. 3A) and the percentage of Th17 cells in $\mathrm{CD}^{+} \mathrm{T}$ lymphocytes population was presented in Fig. 3B. In group (b) $\mathrm{CD}^{+} \mathrm{T}$ lymphocytes were cultured with MAbs and cytokines to promote its differentiation to Th17 cells. In group (c) culture medium also contained IL-35, unlike group (b). It is evident that the level of Th17 cells in
$\mathrm{CD} 4{ }^{+} \mathrm{T}$ lymphocyte population was the highest in group (b) $[\mathrm{P}=0.044$ vs. group (a); $\mathrm{P}=0.048$ vs. group (c)], whereas there was no statistical significance between groups (a) and (c) $(\mathrm{P}=0.946)$.

The mRNA expression levels of IL-35 receptor subunits, including gp130 and IL-12R- $\beta 2$ were separately assayed in all 3 groups. Data were presented as the fold change of gene expression normalized to the endogenous reference gene. As presented in Fig. 3C, the mRNA expression of gp130 was the higher in group (c) compared with group (a) $(\mathrm{P}=0.023)$. The IL-12R- $\beta 2$ mRNA expression was the highest in group (c), although there was no statistical significance $(\mathrm{P}>0.05)$. The mRNA levels of ROR $\gamma \mathrm{t}$ (an important transcription factor of Th17) and IL-17a were also quantified and were the highest in group (b) when compared with the other 2 groups $[\mathrm{P}=0.032$ vs. group (a); $\mathrm{P}=0.046$ vs. group (c) in $\mathrm{ROR} \gamma \mathrm{t}$, and $\mathrm{P}=0.018$ vs. group (a) and $\mathrm{P}=0.023$ vs. group (c) in IL-17a].

\section{Discussion}

The World Health Organization classification defined idiopathic cytopenia of undetermined significance (ICUS) as a condition with dysplastic cells of $<10 \%$ and blasts of $<5 \%$ in $\mathrm{BM}$, which do not fulfill the minimal criteria for myelodysplastic syndromes (MDS) (11). After a period of follow-up, some patients with ICUS were diagnosed as MDS. However, there is still a subset of patients who do not fulfill the criteria for MDS or other diseases even after a thorough follow-up time (12). Our previous study (5) tested IgM and IgG antibodies on various bone marrow cells membrane of various bone marrow cells of patients with ICUS by BMMNC-Coombs 
test, FCM and immunofluorescence analysis and determined that some patients had autoantibodies that lead to the immune dysfunction resulting in the destruction of BM hematopoietic cells and leading to hemocytopenia, which we termed as IRH. It is a type of hemocytopenia regarded as an autoimmune disease caused by unknown autoantibodies, which may suppress bone marrow hematopoietic cells, finally lead to the clinical manifestation of different degrees of anemia, bleeding and infection $(4,5)$.

The IL-12 family is important in autoimmune diseases. IL-12 and IL-23 are involved in pro-inflammatory response. The two occur primarily via IFN- $\gamma$ and IL-17 production that have a role in several autoimmune diseases such as type 1 diabetes $(13,14)$ autoimmune hepatitis $(15,16)$, autoimmune thyroiditis $(17,18)$ rheumatoid arthritis $(19,20)$ ulcerative colitis (21) and CNS inflammatory demyelination (22). IL-27 contributes to anti-inflammatory activities and pro-inflammatory responses. Therefore, these diseases may represent potential targets for immunotherapeutic approaches based on IL-23, IFN- $\gamma$ or IL-17 antagonists or an IL-27 agonist. Anti-IL-12/IL-23 monoclonal antibody, such as ustekinumab has already been used for the treatment of inflammatory bowel disease (23). Additionally, a previous study has been extensively researched in animal and clinical trials that monoclonal antibody targeting IL-17A may be used for the treatment of autoimmune diseases (24). For example, secukinumab, which has already been used for managing plaque psoriasis in clinical practice, may selectively bind to IL-17A molecule and prevents the interaction with target receptors (25).

IL-35 is the newest member of IL-12 family. It is a heterodimeric cytokine that involves two subunits which can be also seen in IL-12 (p35) and IL-27 (EBI3) and is termed a definite immunosuppressor with a high potent of suppression $(26,27)$. T cells (Th1, Th17) may be suppressed via cell cycle termination in the G1 phase. Th1 and Th17 cells may be suppressed via cell cycle termination, not apoptosis (28). A previous study also used an intravitreal injection of pcDNA3.1-IL-35 plasmid into the vitreous cavity of BALB/c mice that boosted the proliferation of Tregs by increasing the expression of IL-10 and TGF- $\beta$ (29). Furthermore, recombinant IL-35 facilitated the function of natural Treg in vitro and reduced the levels of proinflammatory cytokines, such as IL-17 and IFN- $\gamma(30,31)$. Therefore, IL-35 may occur in typel cytokine/type 17 and type 2 immune-inflammatory diseases.

The present study assessed the serum levels of IL-35 in patients with IRH and normal controls. Although some of the findings were close to the detectable dose of the ELISA kit used and results may be influenced by the blocking of the tested antigen binding site or other cytokines, due to the limitations of this method, it is evident that the IL-35 level was significantly reduced in patients with IRH compared to healthy controls. Additionally, IL-35 level in the untreated group was lower than the remission group. It is of note that the serum level of IL-35 was positively correlated with hemoglobin concentration, white blood cell and platelet counts. FCM was used to detect the level of $\mathrm{CD}^{+} \mathrm{CD} 19^{+} \mathrm{B}$ cell gating on $\mathrm{CD} 19^{+}$ B lymphocyte population and lymphocyte population. There was a negative correlation between IL-35 level and level of $\mathrm{CD}^{+} \mathrm{CD} 19^{+} \mathrm{B}$ cell and BMMC autoantibodies have been identified to be produced by $\mathrm{CD}^{+} \mathrm{CD} 19^{+} \mathrm{B}$ cell. As all the clinical data and hematological parameters are associated with the progression of IRH (6), IL-35 may be a biomarker reflecting the activity of IRH and involved in the pathogenesis of IRH. Patients with positive BMMC membrane autoantibodies had lower levels of IL-35 than remission patients with negative BMMC membrane autoantibodies. These findings suggested that IL-35 may be involved in the pathogenesis of IRH and could be used to predict factors for response of treatment with corticosteroids or high-dose IVIG treatment in IRH.

The cause of the decrease of IL-35 level in IRH may be the lower level of Tregs in the patients. Foxp3 has a central role in the differentiation and maintenance of Treg cells. It been previously established that IL-35 is produced primarily by Treg (32). As FoxP3 is a nuclear protein, assessment of its expression in $\mathrm{T}$ cells requires fixation and permeabilization of the cells. Using FCM, the present study determined that the level of Treg was significantly reduced in patients with IRH.

A previous study revealed that the mRNA expressions of the IL-35 subunits (EBI3 and IL-12p35) were reduced in CD4 ${ }^{+}$ $\mathrm{T}$ cells in allergic asthmatics (33) and increased in chronic hepatitis B virus-infected patients $(34,35)$ when compared with normal controls. Conversely, using phased joint embolization in patients with portal hypertension caused by liver cirrhosis may reduce the protein and mRNA expression levels of IL-35 (36). Using cell sorting techniques and RT-qPCR the present study determined the mRNA levels of IL-35 subunits (EBIi3, p35) in $\mathrm{CD} 4^{+} \mathrm{CD} 25^{+} \mathrm{T}$ cells, finding them both decreased in IRH patients compared with the normal controls. This indicated the low expression of IL-35 in $\mathrm{CD} 4{ }^{+} \mathrm{CD} 25^{+} \mathrm{T}$ cells. However, as Foxp3 was not the biomarker used while sorting Tregs, the lower mRNA expression of IL-35 subunits (EBI3, p35) may be associated with the lower level of $\mathrm{CD} 4^{+} \mathrm{CD} 25^{+}$that Foxp3 cells.

Foxp $3^{-/-} \mathrm{T}_{\text {conv }}$ (conventional CD $4^{+}$Foxp $^{-} \mathrm{T}$ cells) cells have already been identified to be converted to IL-35 iT $_{R}$ which express IL-35 and mediate suppression in a manner indistinguishable from their wild type counterparts (37). In addition, $\mathrm{iT}_{\mathrm{R}} 35$ cells do not express Foxp3 following in vivo inoculation (38). The $\mathrm{iT}_{\mathrm{R}} 35$ cell may be suppressive and stable without the expression of Treg transcription factor Foxp3. These types of cells have a positive feedback association with IL-35, as IL-35 suppresses T cell proliferation and converts naïve $\mathrm{T}$ cells into IL-35-producing $\mathrm{iT}_{\mathrm{R}} 35(37,38)$. The lack of IL-35 may lead to the lack of $\mathrm{iT}_{\mathrm{R}} 35$, which may also lead to the low expression of EBI3 and p35 mRNA in CD $4^{+} \mathrm{CD} 25^{+}$Tregs.

It has been previously reported that IL-35 may inhibit the differentiation of $\mathrm{CD}^{+} \mathrm{T}$ lymphocytes to Th17 cells (1). The present study determined that the IL-17 serum level in patients with IRH was higher than that in normal control patients, and it had a negative correlation with the serum level of IL-35. Additionally, the $\mathrm{CD}^{+} \mathrm{T}$ lymphocytes were sorted and cultured with anti-CD3 MAbs, anti-CD28 MAbs, TGF- $\beta$, IL-6 to promote Th17 cell differentiation (39-41) and with IL-35 to determine its effect on Th17 cell differentiation. The findings revealed a lower Th17 level and reduced mRNA expression of ROR $\gamma$ t, IL-17A when IL-35 was added to the mixed-culture system. This demonstrated that IL-35 may inhibit Th17 cell differentiation.

A previous study demonstrated that the hyperfunction of Th17 cells may lead to IRH (8). However, the present study may 
have elucidated an additional reason for Th17 cell hyperfunction: That decreased level of IL-35 can lead to the hyperfunction of Th17 and this decrease may be the pathogenesis of IRH. A previous study had determined that Listeria monocytogenes use IL-27/EBI3 to escape Th17-mediated immune surveillance in IL-12p35-deficient mice (42). IL-35 signals have been identified to encompass three receptor subunits comprising IL-12R- $\beta 2$-IL-12R- $\beta 2$, IL-12R- $\beta 2$-gp130, and gp130-gp130 which activate STAT1 and STAT4 molecules (43-45). Previous studies have revealed that IL-27-mediated suppression of human Th17 cells was associated with the activation of STAT1 $(46,47)$ and IL-27 shares the same subunit EBI3 with IL-35. However, whether IL-35 used the same pathway for suppression of Th17 cell differentiation remains to be elucidated and the mechanism of IL-35 inhibiting Th17 cell differentiation requires further investigation. In conclusion, the present study primarily determined that IL-35 may be a monitoring indicator of progression of IRH and a new therapeutic target for IRH in the future.

Due to its immunosuppressive roles in autoimmunity and inflammation, IL-35 has a pivotal role in controlling effector immunity and may constitute a treatment target in autoimmune diseases. In previous studies on several autoimmune diseases have yielded encouraging results upon IL-35 treatment in animal models. For example, significant remissions of histopathological characteristics of lupus flare and nephritis were observed in MRL/lpr mice (48), alleviations in synovial hyperplasia, cartilage and bone erosion, and fibroblast-like synoviocytes growth were observed in collagen induced arthritis mice $(2,49)$. However, its signaling pathway and further clinical use remain to be fully elucidated.

\section{Acknowledgements}

The present study was supported by the National Natural Science Foundation of China (grant nos. 81570106, 81570111, 81600093,81600088 and 81500101 ) and the Tianjin Municipal Natural Science Foundation (grant nos. 14JCYBJC25400 and 15JCYBJC24300).

\section{References}

1. Collison LW, Workman CJ, Kuo TT, Boyd K, Wang Y, Vignali KM, Cross R, Sehy D, Blumberg RS and Vignali DA: The inhibitory cytokine IL-35 contributes to regulatory T-cell function. Nature 450: 566-569, 2007.

2. Niedbala W, Wei XQ, Cai B, Hueber AJ, Leung BP, McInnes IB and Liew FY: IL-35 is a novel cytokine with therapeutic effects against collagen-induced arthritis through the expansion of regulatory T cells and suppression of Th17 cells. Eur J Immunol 37: 3021-3029, 2007.

3. Kochetkova I, Golden S, Holderness K, Callis G and Pascual DW: IL-35 stimulation of CD39+ regulatory T cells confers protection against collagen II-induced arthritis via the production of IL-10. J Immunol 184: 7144-7153, 2010.

4. Shao Y, Fu R, Liu H, Wang Y, Ding S, Wang H, Li L and Shao Z: $\mathrm{IgG}$ autoantibody subclasses altered in immuno-related hemocytopenia. Cell Immunol 294: 13-20, 2015.

5. Fu R, Liu H, Wang Y, Liu H, He H, Chen J, Wang H, Yu H, Ding K, Huang L, et al: Distinguishing immunorelated haemocytopenia from idiopathic cytopenia of undetermined significance (ICUS): A bone marrow abnormality mediated by autoantibodies. Clin Exp Immunol 177: 412-418, 2014.

6. Fu R, Shao Z, He H, Liu H, Jia H, Sun J, Zhao M, He G, Shi J, Bai J, et al: Quantity and apoptosis-related protein level of B lymphocyte in patients with immunorelated pancytopenia. Zhonghua Xue Ye Xue Za Zhi 23: 236-238, 2002 (In Chinese).
7. Fu R, Chen J, Wang HL, Wang J, Li LJ, Liu H, Wang YH, Ren Y and Shao ZH: Quantity and function of regulatory $\mathrm{T}$ cells in hemocytopenic patients with positive BMMNC-Coombs test. Zhonghua Yi Xue Za Zhi 90: 2989-2993, 2010 (In Chinese).

8. Fu R, Wang HL, Chen J, Wang J, Li LJ, Liu H, Wang YH, Ren Y and Shao ZH: Study of the quantity and function of Th17 cells in the blood cytopenic patients with positive BMMNC-Coombs test. Zhonghua Xue Ye Xue Za Zhi 31: 684-687, 2010 (In Chinese).

9. Zhu X, Guan J, Xu J, Wei J, Jiang L, Yin J, Zhao L and Zhang Y: Pilot study using tacrolimus rather than cyclosporine plus antithymocyte globulin as an immunosuppressive therapy regimen option for severe aplastic anemia in adults. Blood Cells Mol Dis 53: 157-160, 2014.

10. Livak KJ and Schmittgen TD: Analysis of relative gene expression data using real-time quantitative PCR and the 2(-Delta Delta C(T)) method. Methods 25: 402-408, 2001.

11. Valent P, Horny HP, Bennett JM, Fonatsch C, Germing U, Greenberg P, Haferlach T, Haase D, Kolb HJ, Krieger O, et al: Definitions and standards in the diagnosis and treatment of the myelodysplastic syndromes: Consensus statements and report from a working conference. Leuk Res 31: 727-736, 2007.

12. Ando K, Kodama A, Iwabuchi T, Ohyashiki JH and Ohyashiki K: Idiopathic neutropenia with fewer than 5\% dysplasia may be a distinct entity of idiopathic cytopenia of undetermined significance. Ann Hematol 89: 733-735, 2010.

13. Nicoletti F,Zaccone P, Di Marco R, Lunetta M, Magro G, Grasso S, Meroni P and Garotta G: Prevention of spontaneous autoimmune diabetes in diabetes-prone BB rats by prophylactic treatment with antirat interferon-gamma antibody. Endocrinology 138: 281-288, 1997.

14. Nicoletti F, Di Marco R, Zaccone P, Magro G, Di Mauro M, Grasso S and Meroni PL: Endogenous interleukin-12 only plays a key pathogenetic role in non-obese diabetic mouse diabetes during the very early stages of the disease. Immunology 97: 367-370, 1999.

15. Nicoletti F, Zaccone P, Xiang M, Magro G, Di Mauro M, Di Marco R, Garotta G and Meroni P: Essential pathogenetic role for interferon (IFN-)gamma in concanavalin A-induced T cell-dependent hepatitis: Exacerbation by exogenous IFN-gamma and prevention by IFN-gamma receptor-immunoglobulin fusion protein. Cytokine 12: 315-323, 2000.

16. Nicoletti F, Di Marco R, Zaccone P, Salvaggio A, Magro G, Bendtzen K and Meroni P: Murine concanavalin A-induced hepatitis is prevented by interleukin 12 (IL-12) antibody and exacerbated by exogenous IL-12 through an interferon-gamma-dependent mechanism. Hepatology 32: 728-733, 2000.

17. Tang H, Mignon-Godefroy K, Meroni PL, Garotta G, Charreire J and Nicoletti F: The effects of a monoclonal antibody to interferon-gamma on experimental autoimmune thyroiditis (EAT): Prevention of disease and decrease of EAT-specific T cells. Eur J Immunol 23: 275-278, 1993.

18. Zaccone P, Hutchings P, Nicoletti F, Penna G, Adorini L and Cooke A: The involvement of IL-12 in murine experimentally induced autoimmune thyroid disease. Eur J Immunol 29: 1933-1942, 1999.

19. Li R, Zheng X, Popov I, Zhang X, Wang H, Suzuki M, Necochea-Campion RD, French PW, Chen D, Siu L, et al: Gene silencing of IL-12 in dendritic cells inhibits autoimmune arthritis. J Transl Med 10: 19, 2012.

20. Karri SK and Sheela A: Potential route of Th17/Treg cell dynamics in targeting type 1 diabetes and rheumatoid arthritis: An autoimmune disorder perspective. Br J Biomed Sci 74: 8-15, 2017.

21. Dong Z, Du L, Xu X, Yang Y, Wang H, Qu A, Qu X and Wang C: Aberrant expression of circulating Th17, Th1 and Tc1 cells in patients with active and inactive ulcerative colitis. Int J Mol Med 31: 989-997, 2013.

22. Rostami A and Ciric B: Role of Th17 cells in the pathogenesis of CNS inflammatory demyelination. J Neurol Sci 333: 76-87, 2013.

23. Deepak P and Loftus EV Jr: Ustekinumab in treatment of Crohn's disease: Design, development, and potential place in therapy. Drug Des Devel Ther 10: 3685-3698, 2016.

24. Bai F, Tian H, Niu Z, Liu M, Ren G, Yu Y, Sun T, Li S and Li D: Chimeric anti-IL-17 full-length monoclonal antibody is a novel potential candidate for the treatment of rheumatoid arthritis. Int J Mol Med 33: 711-721, 2014.

25. Reszke R and Szepietowski JC: Secukinumab in the treatment of psoriasis: An update. Immunotherapy 9: 229-238, 2017.

26. Vignali DA and Kuchroo VK: IL-12 family cytokines: Immunological playmakers. Nat Immunol 13: 722-728, 2012. 
27. Sun $L$, He C, Nair L, Yeung $J$ and Egwuagu CE: Interleukin 12 (IL-12) family cytokines: Role in immune pathogenesis and treatment of CNS autoimmune disease. Cytokine 75: 249-255, 2015.

28. Olson BM, Sullivan JA and Burlingham WJ: Interleukin 35: A key mediator of suppression and the propagation of infectious tolerance. Front Immunol 4: 315, 2013.

29. Hou C, Wu Q, Ouyang C and Huang T: Effects of an intravitreal injection of interleukin-35-expressing plasmid on pro-inflammatory and anti-inflammatory cytokines. Int J Mol Med 38 713-720, 2016

30. Guan SY, Leng RX, Khan MI, Qureshi H, Li XP, Ye DQ and Pan HF: Interleukin-35: A potential therapeutic agent for autoimmune diseases. Inflammation 40: 303-310, 2017.

31. Egwuagu CE, Yu CR, Sun L and Wang R: Interleukin 35: Critical regulator of immunity and lymphocyte-mediated diseases. Cytokine Growth Factor Rev 26: 587-593, 2015.

32. Hori S, Nomura T and Sakaguchi S: Control of regulatory T cell development by the transcription factor Foxp3. Science 299. 1057-1061, 2003

33. Wang W, Li P, Chen YF and Yang J: A potential immunopathogenic role for reduced IL-35 expression in allergic asthma. J Asthma 52: 763-771, 2015.

34. Zhou Y, Zhang $\mathrm{H}$ and $\mathrm{Li}$ Y: IL-35 expression in peripheral blood CD4(+) T cells from chronic hepatitis B virus-infected patients directly correlates with virus load. Cytokine 73: 169-175, 2015.

35. Shi M, Wei J, Dong J, Meng W, Ma J, Wang T, Wang N and Wang Y: Function of interleukin-17 and -35 in the blood of patients with hepatitis B-related liver cirrhosis. Mol Med Rep 11: 121-126, 2015.

36. Wang Y, Dong J, Meng W, Ma J, Wang N, Wei J and Shi M: Effects of phased joint intervention on IL-35 and IL-17 expression levels in patients with portal hypertension. Int J Mol Med 33: 1131-1139, 2014

37. Collison LW, Chaturvedi V, Henderson AL, Giacomin PR, Guy C, Bankoti J, Finkelstein D, Forbes K, Workman CJ, Brown SA, et al: IL-35-mediated induction of a potent regulatory T cell population. Nat Immunol 11: 1093-1101, 2010.

38. Wong CK, Leung TF, Chu IM, Dong J, Lam YY and Lam CW: Aberrant expression of regulatory cytokine IL-35 and pattern recognition receptor NOD2 in patients with allergic asthma. Inflammation 38: 348-360, 2015.

39. Ghaedi M, Namdari H, Rahimzadeh P, Morteza Gholi S, Azimi Mohamadabadi M and Salehi E: Different doses of transforming growth factor-b on in vitro differentiation of human naive CD4 T cells to T helper 17. Iran J Allergy Asthma Immunol 14: 633-637, 2015.
40. Ghoreschi K, Laurence A, Yang XP, Tato CM, McGeachy MJ, Konkel JE, Ramos HL, Wei L, Davidson TS, Bouladoux N, et al: Generation of pathogenic T(H)17 cells in the absence of TGF- $\beta$ signalling. Nature 467: 967-971, 2010.

41. Volpe E, Servant N, Zollinger R, Bogiatzi SI, Hupé P, Barillot E and Soumelis V: A critical function for transforming growth factor-beta, interleukin 23 and proinflammatory cytokines in driving and modulating human $\mathrm{T}(\mathrm{H})-17$ responses. Nat Immunol 9: 650-657, 2008

42. Chung Y, Yamazaki T, Kim BS, Zhang Y, Reynolds JM, Martinez GJ, Chang SH, Lim H, Birkenbach M and Dong C: Epstein Barr virus-induced 3 (EBI3) together with IL-12 negatively regulates $\mathrm{T}$ helper 17 -mediated immunity to Listeria monocytogenes infection. PLoS Pathog 9: e1003628, 2013.

43. Presky DH, Yang H, Minetti LJ, Chua AO, Nabavi N, Wu CY, Gately MK and Gubler U: A functional interleukin 12 receptor complex is composed of two beta-type cytokine receptor subunits. Proc Natl Acad Sci USA 93: 14002-14007, 1996.

44. Collison LW, Delgoffe GM, Guy CS, Vignali KM, Chaturvedi V, Fairweather D, Satoskar AR, Garcia KC, Hunter CA, Drake CG, et al: The composition and signaling of the IL-35 receptor are unconventional. Nat Immunol 13: 290-299, 2012.

45. Behzadi P, Behzadi E and Ranjbar R: IL-12 family cytokines: General characteristics, pathogenic microorganisms, receptors, and signalling pathways. Acta Microbiol Immunol Hung 63: $1-25,2016$

46. Liu H and Rohowsky-Kochan C: Interleukin-27-mediated suppression of human Th17 cells is associated with activation of STAT1 and suppressor of cytokine signaling protein 1. J Interferon Cytokine Res 31: 459-469, 2011.

47. Peters A, Fowler KD, Chalmin F, Merkler D, Kuchroo VK and Pot C: IL-27 induces Th17 differentiation in the absence of STAT1 signaling. J Immunol 195: 4144-4153, 2015.

48. Cai Z, Wong CK, Dong J, Chu M, Jiao D, Kam NW, Lam CW and Tam LS: Remission of systemic lupus erythematosus disease activity with regulatory cytokine interleukin (IL)-35 in Murphy Roths Large (MRL)/lpr mice. Clin Exp Immunol 181: 253-266, 2015.

49. Li Y, Wu S, Li Y, Jiang S, Lin T, Xia L, Shen H and Lu J: Interleukin-35 (IL-35) inhibits proliferation and promotes apoptosis of fibroblast-like synoviocytes isolated from mice with collagen-induced arthritis. Mol Biol Rep 43: 947-956, 2016 